\title{
Status and conservation of seabirds breeding in Argentina
}

\author{
PABLO YORIO, ESTEBAN FRERE, PATRICIA GANDINI and WILLIAM \\ CONWAY
}

\section{Summary}

We present information on the current population status of seabirds that breed along the Patagonian coast obtained between 1993 and 1995. A total of 16 species, including two penguins, one petrel, five cormorants, three gulls, three terns and two skuas, breed along the $3,400-\mathrm{km}$ coast from southern Buenos Aires ( $\left.38^{\circ} 58^{\prime} \mathrm{S}\right)$ to Tierra del Fuego $\left(54^{\circ} 50^{\prime} \mathrm{S}\right.$ ). Breeding seabirds are not as abundant in coastal Argentina as was previously thought. Eleven of the 16 species have less than 5,000 pairs. The most abundant seabird is the Magellanic Penguin Spheniscus magellanicus with 964,000 pairs, an order of magnitude higher than all other species. As well as Magellanic Penguins, Kelp Gulls Larus dominicanus, and Imperial Cormorants Phalacrocorax atriceps are relatively abundant and have a wide distribution. Other seabirds, such as Red-legged Cormorants $P$. gaimardi, Olrog's Gulls L. atlanticus, and Dolphin Gulls L. scoresbii, have a highly restricted distribution or nest in small colonies at a few sites in Argentina. The Patagonian coast is one of the most pristine coastal ecosystems in the world and, thus far, few seabirds are seriously threatened. However, oil pollution and commercial fisheries are having a negative impact on some seabirds and some colonies have shown recent declines. Current threats and impacts, including pollution, fisheries, human disturbance, guano harvesting, and introduction of alien species are discussed. There are currently 34 protected coastal areas, although in many cases protection measures are not adequately enforced and some areas with high seabird diversity and abundance still lack legal and effective protection. Conservation actions and requirements, including direct actions, monitoring and research are suggested.

\section{Introduction}

Patagonia has a large and diverse coastline offering many breeding sites suitable for seabirds. A total of 16 species, including two penguins, one petrel, five cormorants, three gulls, three terns and two skuas, breed along the $3,400 \mathrm{~km}$ coast from southern Buenos Aires $\left(38^{\circ} 58^{\prime} S\right.$ ) to Tierra del Fuego ( $\left.54^{\circ} 50^{\prime} \mathrm{S}\right)$. The Patagonian coastal zone is one of the few relatively pristine coasts in the world, although it is exposed at many locations to fast growing economic activities. Due to their demographic characteristics and colonial habits, seabirds are very vulnerable to some of these activities, such as oil extraction and transport, fisheries and human disturbance at their colonies.

Several papers present information on distribution and abundance of Patagonian seabirds (Carrara 1952, Zapata 1965, Humphrey et al. 1970, Boswall and Prytherch 1972, Daciuk 1977a, Devillers 1978, Scolaro et al. 1980, Malacalza 1984, 
Capurro et al. 1988, Punta 1989, Frere et al. 1993, Pagnoni et al. 1993, Punta and Saravia 1993, Yorio et al. 1994, Gandini and Frere 1995, 1996, Schiavini and Yorio 1995, Bertellotti et al. 1995, Pérez et al. 1995, Gandini et al. 1996, Yorio and Harris 1997, Yorio et. al. 1997). However, such studies have been focused on a single species or location or referred to just a sector of the Patagonian coastline. Although very valuable, this information is inadequate for the development of national conservation and management strategies, as these require knowledge of the distribution and abundance at a regional scale for all seabird species.

Between 1993 and 1995, a programme aimed at the evaluation of Patagonian breeding seabirds was developed within the Patagonian Coastal Zone Management Plan, a Global Environmental Facility (GEF)/United Nations Development Programme (UNDP) project. This paper summarizes information on the current population status of seabirds that breed along the Patagonian coast, obtained during this programme and presented in greater detail in Yorio et al. (1998), reviews the main impacts and threats seabirds face in the region, and discusses conservation and research needs.

\section{Methods and data sources}

Between 1993 and 1995, seabird population evaluations were conducted within the Patagonian Coastal Zone Management Plan (PCZMP), a GEF/UNDP project implemented in association with several governmental and non-governmental Patagonian organizations. All breeding sites identified during an aerial survey of the coast between Bahía Blanca $\left(39^{\circ} 06^{\prime} \mathrm{S}, 62^{\circ} \mathrm{Og} 9^{\prime} \mathrm{W}\right)$ and the Strait of Magellan $\left(52^{\circ} 24^{\prime} \mathrm{S}, 6^{\circ} 26^{\prime} \mathrm{W}\right)$ conducted during November 1990 (Yorio and Harris 1997) were visited and censused. In addition, sections of the Provinces of Buenos Aires, Río Negro, Chubut, and Santa Cruz coasts were surveyed by plane and boat, and all new seabird colonies encountered were censused (see Gandini et al. 1998). All surveys and colony size estimations were made during incubation and early chick stage (late October to early December, depending on the species and location). Additional information on distribution and abundance of seabird colonies in Tierra del Fuego Province is based on Schiavini et al. (1998).

Colony sizes were obtained using different census methods depending on the species and habitat characteristics: full nest-counts, nest-estimations using circular plots, and aerial counts (Bibby et al. 1992, Frere and Gandini 1996). Magellanic Penguins Spheniscus magellanicus and Kelp Gulls Larus dominicanus were censused by full nest-counts and by estimations using circular plots (Frere and Gandini 1996). Imperial Cormorant Phalacrocorax atriceps and Southern Giant Petrel Macronectes giganteus colony sizes were obtained by counting nests from aerial photographs. The sizes of Olrog's Gull Larus atlanticus colonies were obtained, depending on the breeding site, by full nest counts in the colony or from aerial photographs. The rest of the species were censused by full nest counts from the ground. Population trends were assessed using information obtained from the literature and from annual estimations of colony sizes made throughout the PCZMP.

\section{The breeding seabirds}

Sixteen seabirds breed along the Patagonian coast (Table I). In addition, one pair of Gentoo Penguins has been breeding at Isla Martillo, Beagle Channel, for the 
Table 1. Number of breeding sites, percentage of sites where a census was conducted between 1990 and 1995, and the estimated breeding population (in breeding pairs) of seabirds in coastal Argentina, from Bahía Blanca, Buenos Aires, to the Beagle Channel, Tierra del Fuego

\begin{tabular}{lccr}
\hline Species & $\begin{array}{c}\text { Number of } \\
\text { breeding sites }\end{array}$ & $\begin{array}{c}\text { Percentage of } \\
\text { sites evaluated }\end{array}$ & $\begin{array}{r}\text { Estimated total } \\
\text { population size } \\
\text { (breeding pairs) }\end{array}$ \\
\hline Megallanic Penguin Spheniscus magellanicus & 60 & 100 & 964,000 \\
Rockhopper Penguin Eudyptes chrysocome & 3 & 33 & $180^{\text {a }}$ \\
Southern Giant Petrel Macronectes giganteus & 4 & 75 & 2,310 \\
Imperial Cormorant Phalacrocorax atriceps & 54 & 94 & 48,940 \\
Rock Shag P. magellanicus & 143 & 93 & 7,530 \\
Red-legged Cormorant P. gaimardi & 13 & 100 & 1,090 \\
Olivaceous Cormorant P. olivaceus & 12 & 100 & 1,210 \\
Guanay Cormorant P. bougainvillii & 2 & 100 & 9 \\
Kelp Gull Larus dominicanus & 104 & 89 & 74,300 \\
Dolphin Gull L. Scoresbii & 26 & 92 & 620 \\
Olrog's Gull L. atlanticus & 10 & 100 & 2,310 \\
South American Tern Sterna hirundinacea & 23 & 74 & 16,320 \\
Cayenne Tern S. eurygnatha & 11 & 73 & 2,830 \\
Royal Tern S. maxima & 5 & 60 & 780 \\
Skuas (Southern and Chilean) Catharacta & 36 & 100 & 530 \\
antarctica and C. chilensis & & & \\
\hline
\end{tabular}

aSee text

past decade (Schiavini and Yorio 1995) but is excluded from the current analysis. At least one more species is a potential breeder in the region. Magellanic and Common Diving Petrels Pelecanoides magellani and P. urinatrix are regularly observed along the Beagle Channel (Schiavini and Yorio 1995) and diving petrel calls were heard on cliffs at Isla de los Estados during November 1995 (Schiavini and Frere unpubl. data). Breeding of these two species, however, has not been confirmed. In addition, given the characteristics of the coasts of Isla de los Estados and southern Tierra del Fuego, we can not rule out the possibility of occurrence of other small, nocturnal petrels whose nests are difficult to detect and which also breed in the Cape Horn area (Clark et al. 1992). Brown-hooded Gulls Larus maculipennis and Trudeau's Tern Sterna trudeaui breed mostly at inland locations in Argentina and are not treated as seabirds in this paper. Brown-hooded Gull colonies were found at only two sites on the marine coast in southern Buenos Aires (Yorio and Harris 1997) and isolated pairs have been recorded at one location in Río Negro (González et al. 1998). Trudeau's Tern has been reported to breed, in very small numbers, at only one site in Río Negro (González et al. 1998). Kelp Gulls, Olivaceous Cormorants Phalacrocorax olivaceus and, to a lesser extent, Imperial Cormorants also breed inland and population information presented in this paper eventually should be integrated with data from inland sites to obtain a more complete interpretation of population and conservation status.

\section{Magellanic Penguin Spheniscus magellanicus}

Magellanic Penguins are widely distributed in Patagonia. They breed from Península Valdés $\left(42^{\circ} \mathrm{S}\right)$, Chubut, to the Beagle Channel $\left(54^{\circ}\right)$, Tierra del Fuego (Gandini et al. 1996). The Magellanic Penguin is the most abundant species, with 
a total population size of approximately 964,000 breeding pairs (Table 1 ). Colony sizes range from a few to 175,000 nests. Despite its abundance and wide distribution, the Magellanic Penguin is one of the most vulnerable species to human activities because of its special natural history. It is the seabird most affected by oil pollution and incidental capture in fishing nets. In addition, Magellanic Penguins are very charismatic and breed in large colonies, making them an important tourist attraction and vulnerable to mismanagement of visitors at their colonies. Even though lack of previous population data on most colonies makes difficult the identification of general trends, the monitoring of selected colonies shows important variations in the population size at certain sites. For example, the colonies of Punta Tombo and Cabo Dos Bahías have decreased in size during the last decade ( 20 and $25 \%$, respectively; D. Boersma unpubl. data), while colonies at Península Valdés, Punta Buque, Estancia 8 de Julio, and Isla Deseada have increased (Carribero et al. 1995, Gandini et al. 1996).

\section{Rockhopper Penguin Eudyptes chrysocome}

Rockhopper Penguins have been recorded breeding at Isla Pingüino $\left(47^{\circ} 45^{\prime} \mathrm{S}\right.$, $65^{\circ} 54^{\prime} \mathrm{W}$ ), Santa Cruz (Frere et al. 1993), and at two sites in Isla de los Estados, Tierra del Fuego (Schiavini et al. 1998). Isla Pingüino, where 180 pairs nest, is the northernmost breeding location of this species. The total breeding population in Isla de los Estados was estimated to be several thousand pairs (Schiavini et al. 1998).

\section{Southern Giant Petrel Macronectes giganteus}

Southern Giant Petrels breed at only four known locations in the region. Two colonies of 490 and 1650 pairs, are located on islands in southern Chubut (Isla Arce and Isla Gran Robredo). Two other colonies are known from Isla de los Estados, Tierra del Fuego, one of which was estimated to have 181 pairs (Schiavini et al. 1998).

\section{Imperial Cormorant Phalacrocorax atriceps}

The breeding distribution of the Imperial Cormorant in coastal Argentina ranges from Punta León $\left(43^{\circ}\right.$ S), Chubut, to the Beagle Channel ( $54^{\circ}$ S), Tierra del Fuego. Many Imperial Cormorant colonies in Patagonia include both "albiventer" and "atriceps" colour morphs, sensu Siegel-Causey (1986). The relationship between $P$. atriceps and $P$. albiventer is still a matter of discussion. In this paper, we follow Rasmussen's (1991) treatment, and consider both as Imperial Cormorant $P$. atriceps until clarification of the taxonomic status of the species. A total of 54 colonies has been identified, with sizes that vary between 20 and 5,800 nests. It is the third most abundant species in the region, with an estimated 48,940 breeding pairs (Table 1), and an important economic resource at a local scale, as Imperial Cormorants are the main guano producers in Patagonia. Monitoring of colonies in Chubut and Santa Cruz has shown that while some of them have increased in size during the past five years, many, especially along the Santa Cruz coast (Frere and Gandini unpubl. data), have shown a significant decrease. However, 
the total increase in number of pairs at some colonies has not off-set the overall decrease observed for the Patagonian coast.

\section{Rock Shag Phalacrocorax magellanicus}

Rock Shags were found breeding in relatively small colonies of between a few and 380 nests. A total of 143 breeding sites have been recorded between Península Valdés, Chubut $\left(42^{\circ} \mathrm{S}\right)$ and the Beagle Channel $\left(54^{\circ} \mathrm{S}\right)$, Tierra del Fuego, with a total population size of 7,530 breeding pairs.

\section{Red-legged Cormorant Phalacrocorax gaimardi}

Breeding colonies of the Red-legged Cormorant are restricted to the Province of Santa Cruz, between $47^{\circ} 05^{\prime} \mathrm{S}$ and $50^{\circ} 23^{\prime} \mathrm{S}$. A total of 1,090 breeding pairs were found nesting at 13 colonies, ranging in size between 5 and 625 nests (Gandini and Frere 1995). More than half of the population (625 pairs) was recorded breeding at only one location (La Mina, $49^{\circ} 10^{\prime} \mathrm{S}, 67^{\circ} 36^{\prime} \mathrm{W}$ ).

\section{Olivaceous Cormorant Phalacrocorax olivaceus}

Olivaceous Cormorants were observed breeding at 12 sites, from Complejo Islote Lobos $\left(47^{\circ} 27^{\prime} \mathrm{S}\right)$, Río Negro, to Bahía San Julián $\left(49^{\circ} 16^{\prime} \mathrm{S}\right)$, Santa Cruz. Colony sizes varied between 30 and 356 nests, and a total breeding population was estimated at 1,200 pairs. Olivaceous Cormorants are commonly found breeding inland along rivers and lakes throughout Argentina.

\section{Guanay Cormorant Phalacrocorax bougainvillii}

Guanay Cormorants currently breed at only two locations in the Chubut coast: Punta León (three pairs) and Punta Lobería (six pairs). Guanay Cormorants were first recorded in Argentina in the late 1960s, when about 50 pairs were observed breeding among Imperial Cormorants at Punta Tombo $\left(44^{\circ}{ }^{\circ} 2^{\prime} \mathrm{S}, 65^{\circ} 11^{\prime} \mathrm{W}\right)$ (Erize 1972, W. Conway unpubl. data). Guanay Cormorants were observed breeding at Punta Tombo throughout the 1970 (W. Conway unpubl. data) and the last published record at that site is from 1981 (Malacalza 1984). Hybrids of Guanay and Imperial Cormorants have been reported at Punta León (Malacalza 1991).

\section{Southern and Chilean Skuas Catharacta antarctica and C. chilensis}

Southern and Chilean Skuas breed along the Patagonian coast. Both species nest together at some locations, such as Isla Viana $\left(45^{\circ} 11^{\prime} \mathrm{S}, 66^{\circ} 24^{\prime} \mathrm{W}\right)$ Isla Pinguino $\left(47^{\circ} 55^{\prime} \mathrm{S}, 65^{\circ} 43^{\prime} \mathrm{W}\right)$ and Punta Buque $\left(4^{\circ} \mathrm{O} 7^{\prime} \mathrm{S}, 65^{\circ} 57^{\prime} \mathrm{W}\right)$. Given the difficulty of discriminating between skua species under survey conditions, both species are treated together in this paper. Skuas were found nesting at 36 sites in numbers that ranged between one and 131 pairs. 


\section{Kelp Gull Larus dominicanus}

The breeding distribution of the Kelp Gull in coastal Argentina ranges over 3,400 $\mathrm{km}$ of coastline, from the Bahía Blanca estuary, southern Buenos Aires $\left(38^{\circ} 58^{\prime} \mathrm{S}, 62^{\circ} 19^{\prime} \mathrm{W}\right)$ to Bahía Ushuaia, Tierra del Fuego $\left(54^{\circ} 51^{\prime} \mathrm{S}, 68^{\circ} 16^{\prime} \mathrm{W}\right)$. A total of 104 breeding colonies was identified. Median colony size was 183 pairs, ranging from two to 12,260 breeding pairs. It is the second most abundant seabird in the region, with more than 74,300 breeding pairs. At least one more coastal breeding site is known north of Bahía Blanca, at Claromecó, Buenos Aires $\left(38^{\circ} 45^{\prime} \mathrm{S}, 59^{\circ} 28^{\prime} \mathrm{W}\right)$ (G. Francia pers. comm.). Kelp Gulls are feeding generalists and take advantage of artificial food sources resulting from human activities, such as refuse tips, sewage outfalls, slaughter houses and fisheries by-catch (Yorio et al. 1996a, Giaccardi et al. 1997). At least seven Kelp Gull colonies for which previous size estimations exist have shown an increase in breeding pairs (Bertellotti et al. 1995, Yorio et al. in press).

\section{Dolphin Gull Larus scoresbii}

Dolphin Gulls breed from Punta Tombo $\left(44^{\circ} \mathrm{S}\right)$, Chubut, to the Beagle Channel $\left(54^{\circ} \mathrm{S}\right)$, Tierra del Fuego. The total number of breeding pairs for the region was estimated at less than 700, distributed in 26 colonies of between five and 120 nests. The Dolphin Gulls appears to be mostly dependent on other species for food during the breeding cycle (Yorio et al. 1996b), possibly restricting its choice for breeding habitats.

\section{Olrog's Gull Larus atlanticus}

Olrog's Gull is an endemic species of the Argentine coast. The breeding geographical range of the Olrog's Gull is very small $\left(39^{\circ} 12^{\prime}\right.$ to $\left.45^{\circ} 11^{\prime} \mathrm{S}\right)$, restricted to only two nesting areas: southern Buenos Aires (Bahía Blanca Estuary and Bahía Anegada) and north of Golfo San Jorge, Chubut (Bahía Melo and Caleta Malaspina) (Yorio et al. 1997). The total population size was estimated at 2,300 pairs, breeding in 10 colonies of between 15 and 800 nests. Current available information suggests that Olrog's Gull has a fairly specialized feeding ecology, taking mainly crabs (Collar et al. 1992, Spivak and Sánchez 1992, G. Herrera and G. Punta unpubl. data). This species is internationally considered as "threatened" (Collar et al. 1992).

\section{South American Tern Sterna hirundinacea}

The breeding distribution of the South American Tern ranges from Punta Bermeja ( $\left.41^{\circ} \mathrm{O} 9^{\prime} \mathrm{S}\right)$, Río Negro, to the Beagle Channel $\left(54^{\circ} \mathrm{S}\right)$, Tierra del Fuego. A total of 23 colonies were identified, ranging between one and over 3,000 nests. The total breeding population exceeds 16,300 pairs (Table 1 ). This species has been observed to change colony sites between breeding seasons (Bertellotti $e t$ al. 1995, Scolaro et al. 1996) and breeding may take place from November to January. Changes in colony location and unpredictable timing of breeding did not allow an accurate estimation of its populations during the study period. 


\section{Cayenne Tern Sterna eurygnatha}

Cayenne Terns are considered by some authors to be a race or colour morph of the Sandwich Tern Sterna sandvicensis (Gochfeld and Burger 1996). The breeding distribution of Cayenne Terns ranges from Banco Culebra $\left(40^{\circ} 22^{\prime} \mathrm{S}\right)$, southern Buenos Aires, to Ría Deseado $\left(47^{\circ} 48^{\prime} \mathrm{S}\right)$, Santa Cruz. A total of 11 colonies have been identified, and the size of the eight colonies which were censused ranged between 30 and 1,140 nests. This species has been observed to change colony sites between breeding seasons. All Cayenne Tern colonies were found to be associated with either Royal or South American Terns.

\section{Royal Tern Sterna maxima}

Royal Terns were recorded breeding at five colonies from Banco Culebra $\left(40^{\circ} 22^{\prime} \mathrm{S}\right)$, southern Buenos Aires, to Monte Loayza $\left(47^{\circ} \mathrm{O} 5^{\prime} \mathrm{S}\right)$, Santa Cruz. The size of the three colonies which were censused ranged between 11 and 690 nests. As in the other two tern species, Royal Terns have been observed to change colony sites between breeding seasons. All Royal Tern colonies were found to be associated with either Cayenne or South American terns.

\section{Patterns of distribution and abundance}

The information presented on seabird distribution and abundance reveals some unexpected patterns. First, breeding seabirds are not as abundant in coastal Argentina as previously thought. Most species have relatively small total breeding populations: 11 of the 16 species $(69 \%)$ have fewer than 5,000 pairs. Second, the most abundant seabird is the Magellanic Penguin, which has a total breeding population an order of magnitude higher than all other species. The relative importance of the Magellanic Penguin in coastal ecosystems is still more significant if considered in terms of biomass, as they weigh between 4 and $5 \mathrm{~kg}$ (Boersma et al. 1990), two to ten times more than any other censused seabird.

Some Patagonian seabirds are relatively abundant and have a wide distribution, breeding at many sites along the coast, while others have a highly restricted distribution or nest in small colonies at a few sites. For example, Kelp Gulls are relatively abundant, breeding from southern Buenos Aires to the Beagle Channel in about 100 colonies. In contrast, Olrog's Gull has a very restricted distribution and breeds in only 10 colonies. Dolphin Gulls have a wide distribution but a small number of breeding pairs nest at only 26 sites along the coast. The pattern of distribution and abundance of these three gulls possibly reflects interspecific differences in the use of resources, as Kelp Gulls are apparently food and habitat generalists (Yorio et al. in press), while Dolphin and Olrog's Gull appear to have specialized requirements (Yorio et al. 1996b, Yorio et al. 1997). Flexibility in habitat and food requirements might also be contributing to the observed expansion of the Kelp Gull (see above). A similar pattern of distribution and abundance is observed in the cormorants. The Imperial Cormorant is widely distributed and abundant, the Rock Shag is widely distributed but nests in relatively small colonies and has a small total population size, and the Red-legged Cormorant has a restricted distribution and a small population size. 


\section{Threats and impacts}

\section{Commercial fisheries}

Fishing is one of the most important economic activities along the Patagonian coast. More than one million tons are annually harvested from the Argentine continental shelf and annual catch is still increasing. Although no quantitative study has yet been conducted to analyse seabird-fishery interactions, preliminary information shows that Magellanic Penguins and to a lesser extent Sooty Shearwaters are regularly incidentally caught in nets during fishing operations ( $E$. Frere and P. Gandini unpubl. data). Imperial Cormorants and Black-browed Albatrosses are also occasionally killed (E. Frere and P. Gandini unpubl, data). Little is known about the potential competition for food between seabirds and high seas fisheries, although it has been suggested that, at least for Magellanic Penguins, conflicts with commercial fisheries through resource competition might occur in northern Patagonia (Frere et al. 1996).

Small-scale fisheries also operate along the coast, overlapping in many cases with seabird foraging areas. However, recent studies have shown that coastal fisheries have a small impact on seabirds in terms of incidental catches. Magellanic Penguins, Imperial Cormorants and Greater Shearwaters are only occasionally killed during trawling operations by coastal vessels (Yorio and Caille 1999). In addition, at least 23 seabirds that breed or forage in coastal waters, mainly Kelp Gulls and Black-browed Albatrosses, regularly associate with coastal fishing activities, mostly to scavenge fishery waste (Yorio and Caille 1999).

\section{Pollution}

Among marine pollutants, petroleum pollution is currently the major threat to Patagonian seabirds. Chronic oil pollution still persists throughout the coastal zone (Commendatore et al. 1996). The Magellanic Penguin is the most affected species, although other seabirds such as the Rockhopper Penguin and some gulls, terns and cormorants, are regularly found oiled along the coast (Gandini et al. 1994). Oil pollution may annually kill thousands of birds and, in some cases, may result in a decrease in seabird productivity. For example, an estimated 20,000 adult and 22,000 juvenile Magellanic Penguins are killed every year in Argentina as a result of chronic oil pollution (Gandini et al. 1994). It has also been shown that petroleum fouling in Magellanic Penguins can suppress circulating levels of reproductive hormones and interfere with breeding (Fowler et al. 1995).

Heavy metals, such as lead and cadmium, have been detected in Magellanic Penguins and Kelp Gulls (Gil et al. 1997). Organochlorine pesticides have also been detected in Magellanic Penguins and Kelp Gulls, with similar levels of pp'DDE to those found in birds sampled in the South Atlantic but lower than those recorded in heavily polluted areas of the Northern Hemisphere (Gil et al. 1997). Nevertheless, an adequate evaluation of the impact on seabirds by heavy metals and organochlorine pesticides requires further studies, including the analysis of pollutants on other species and areas in northern Patagonia. 


\section{Human disturbance}

Several seabird colonies are visited by national and international tourists throughout the breeding season (Yorio et al. 1996c). Magellanic Penguins are one of the main tourist attractions in coastal Patagonia (Tagliorette and Losano 1996). Current information suggests that ecotourism in Patagonia is compatible with the breeding of Magellanic Penguins if the visits are controlled (Yorio and Boersma 1992, Gandini and Frere 1996). However, seabirds show different sensitivity to human disturbance, and the inappropriate behaviour of people during their visits to colonies often results in reduced breeding success in most species (Vila and Pérez 1996, Yorio and Quintana 1996, Yorio et al. 1996c).

\section{Direct exploitation and guano extraction}

Seabirds at many sites on the Patagonian coast, such as certain islands in the north of Golfo San Jorge and Isla de los Estados, were subject to human exploitation until the beginning of the twentieth century. Magellanic Penguins were harvested from colonies in Chubut and Santa Cruz (Carrara 1952, Godoy 1963) and Rockhopper and King Penguins Aptenodytes patagonicus from Isla de los Estados (Chebez and Bertonatti 1994). Intense harvesting of King Penguins has been suggested as the main cause of the local extinction of this species at Isla de los Estados (A. Schiavini pers. comm.). Penguins and cormorants were also used during the mid-1970s for crab bait in the king crab Paralomis granulosa fishery (Schiavini and Yorio 1995). Even though proposals to harvest Magellanic Penguins for commercial purposes have been presented in Argentina in the recent past, no colonies are currently being exploited. Conservation awareness in Patagonia currently precludes any attempt at harvesting Magellanic Penguins. Besides, benefits from ecotourism are high, so discouraging penguin harvest.

Harvesting of Magellanic Penguin, Rockhopper Penguin, Kelp Gull, Olrog's Gull and South American Tern eggs was common in the past at some locations (Devillers 1977, Chebez and Bertonatti 1994, Schiavini and Yorio 1995). However, this activity is now restricted to a very few places, such as Bahía San Blas and Bahía de San Antonio, where collection of Kelp Gull and South American Tern eggs is carried out by local people for subsistence, not commercial, purposes. The effects of egging on seabird populations has not been evaluated, but it appears that the collection of Kelp Gull eggs has contributed to the recent decline of the Cabo Virgenes colony (Frere and Gandini unpubl. data). Disturbance created by this activity might be more harmful than the collection of eggs and could also affect other species which share nesting sites with gulls and terns.

Guano exploitation to use as a fertilizer is an important activity for local economies in Chubut and Santa Cruz (Punta 1996). The guano is obtained mainly at Imperial Cormorant colonies, with 11 of the 54 colonies currently opened for exploitation. These colonies represent about $35 \%$ of the total Imperial Cormorant population. Guano harvesting during the non-breeding season and the use of appropriate extraction methods can allow, theoretically, the development of a guano industry with little impact on cormorants. However, no studies have yet evaluated the impact of harvesting activities on settlement and recruitment patterns or on cormorant breeding success in Patagonia. 


\section{Introduced species and habitat degradation}

Seabirds breed at more than 140 islands and islets along the Argentine coast, and most are bare rocky islands that appear to be too small to hold viable populations of mammalian predators. However, alien mammal predation may be a growing threat at Isla de los Estados, a 50o- $\mathrm{km}^{2}$ island located south-east of Tierra del Fuego. Goats were introduced to Isla de los Estados by a sealer during the middle of the last century, and Norway rats Rattus norvegicus were introduced by ships on several occasions and are now widespread on the island (A. Schiavini unpubl. data).

\section{Gull population expansion and conflicts with man}

Kelp Gulls, and to a lesser extent Dolphin Gulls and Southern Skuas, feed on domestic refuse and fishery waste at city dumps. The most abundant and widely distributed species in coastal dumps is the Kelp Gull. More than 7,000 individuals can be recorded on a single count at some sites along the coast (Yorio et al. 1996a). During winter surveys, the number of adult gulls at all coastal refuse tips may represent up to $20 \%$ of the total Patagonian breeding population (Yorio et al. 1996a). This suggests that artificial food sources may be playing an important role in the population increase of several Kelp Gull colonies in Patagonia.

The increase in Kelp Gull populations may result in negative impacts on other coastal species through predation, competition for breeding space, and kleptoparasitism (Yorio et al. in press). The increase in the number of gulls and their activity at or near cities may also result in conflicts with human populations. Several pathogens, such as Klebsiella, Salmonella and Shigella were identified in Kelp Gull faeces sampled in garbage dumps at Puerto Madryn, Rawson, and Puerto Deseado (Yorio et al. 1996a). Kelp Gulls might also represent a threat to aircraft, although currently this is not a significant problem in coastal Argentina. Gulls have been reported to affect airport traffic at Trelew, Comodoro Rivadavia, and San Antonio Oeste (Yorio et al. in press).

\section{Current protection}

Of all breeding species in Patagonia, Olrog's Gull is the only one formally categorized as "threatened" (Collar et al. 1992). However, human activities are now having a negative impact on some seabirds and some colonies have shown recent declines. Even though most species are not threatened, it is worth noting that several, such as Red-legged Cormorant, Dolphin Gull, Southern Giant Petrel and Royal Tern, have very small Patagonian breeding populations.

There are currently 34 coastal areas with some kind of protected status, although in many cases protection measures are not adequately enforced. A few of these reserves protect a large proportion of the Patagonian population of a given species and are therefore of great importance. For example, "Punta Tombo" Reserve protects $18 \%$ of breeding Magellanic Penguins and "Bahía Blanca, Bahía Falsa y Bahía Verde" Reserve $39 \%$ of breeding Olrog's Gulls. Some seabirds are relatively well protected: all Rockhopper Penguins and $99 \%$ of Redlegged Cormorants breed within wildlife reserves. On the other hand, only $20 \%$ 
of Rock Shags and 25\% of Dolphin Gulls breed in protected areas. A few reserves include tern colonies, although the nomadic behaviour of Patagonian species requires the designation of a reserve network, including locations which do not hold any kind of wildlife during some years, to provide for adequate protection. In addition, some important areas with high seabird diversity and abundance still need legal and effective protection. These include most islands within and near Bahía Melo and Bahía Bustamante, Islas Leones, Punta Buque and the Beagle Channel.

Most current wildlife reserves do not provide an adequate protection for breeding seabirds. Only a few protected areas include a small part of their adjacent waters within their boundaries and, in general, waters where seabirds forage, winter and/or migrate are not protected at all. Magellanic Penguins migrate north, many of them reaching up to Uruguay and southern Brazil (Daciuk 1977b, Boersma et al. 1990, Frere et al. 1996). Olrog's Gull also migrates north reaching the coasts of northern Buenos Aires and Uruguay (Collar et al. 1992). Other species such as Royal and Cayenne Terns also disperse north and may reach the coasts of Uruguay. However, no conservation or management actions have been implemented to protect these species throughout their migration routes. Agreements for international co-operation in this respect are also lacking, although Olrog's Gull has been recently included in appendix I of the Convention for the Conservation of Migratory Species.

\section{Conservation action and requirements}

A seabird conservation plan for the coast of Argentina must be comprehensive enough to assure the long-term survival of its 16 species of breeding seabirds. To that end, sufficient numbers of breeding sites and feeding areas should be protected and managed in an integrated fashion to sustain viable populations of each species, not alone in individual and uncoordinated provincial programmes.

\section{Direct actions}

- Enlarge the area currently protected by reserves, by including Islas Blancas, Islas Leones, Bahía Melo, Bahía Bustamante, Caleta Malaspina, Punta Buque, and Bahía Ushuaia. Identify key sites that, because of their status, structure or location, should remain closed to human visitation.

- Improve legal protection of Olrog's Gull by extending existing reserves to include the Islote Colina de los Riachos at the Bahía San Blas Reserve and designate appropriate areas in southern Chubut to include the southern population.

- Integrate management plans and actions by means of formal co-operative programmes, including those aspects of fisheries, oil transport, coastal development and tourism which have been shown to affect seabirds.

- Increase and integrate efforts to prevent marine pollution, particularly oil pollution, and work with oil company personnel and with local and national authorities to improve and enforce anti-pollution regulations.

- Seek expert help to control the alien mammals introduced on Isla de los Estados. 
- Improve current legislation protecting seabirds and the marine environment.

- Working with the appropriate authorities, seek to develop a strategy and international agreements to protect species that disperse outside Argentine jurisdiction at some part of their annual cycle.

\section{Research and monitoring}

- A complete survey should be undertaken at least every five years. Annual seabird surveys should be made at all heavily visited reserves.

- Initiate thorough surveys and censuses for the coastal section of southern Buenos Aires Province and for the three tern species throughout the Patagonian coast. Thorough surveys, particularly for small petrels, are also needed for Isla de los Estados, Province of Tierra del Fuego.

- Implement annual surveys at major colonies in decline, such as the Magellanic Penguin colonies at Punta Tombo and Cabo Dos Bahías and the Imperial Cormorant colonies at Isla Chata; Monte León, and Isla Rasa Chica, and at those newly subject to human activity.

- Include regular monitoring of all seabird areas to discover and report the appearance of alien mammal predators.

- Increase research on the interdependence between seabirds and the marine environment, particularly diet, foraging areas, and predator-prey relationships. Increase research on short- and long-term climatic changes (including El Niño effects), establishment of new populations and interactions between seabirds and marine mammals.

- Increase research on seabird-fishery interactions.

- Promote research on sustainable use, especially the relationship between seabirds and tourism, noting the recommendations of the PCZMP (Fundación Patagonia Natural 1996).

- Analyse the relationship between the seabirds of Argentina's coast and those in Uruguay, Brazil, Chile and Islas Malvinas (Falkland Islands) to determine to what extent shared species constitute metapopulations whose fortunes affect one another.

\section{Acknowledgements}

Information on seabird distribution and abundance was collected as part of the Patagonian Coastal Zone Management Plan, a Global Environmental Facility/United Nations Development Programme project implemented by Fundación Patagonia Natural and Wildlife Conservation Society. We thank all those people (too numerous to thank individually) who participated in the seabird population evaluations. We thank Centro Nacional Patagónico, Universidad Nacional de la Patagonia Austral, Fundación Patagonia Natural and Wildlife Conservation Society for institutional support.

\section{References}

Bertellotti, M., Carribero, A. and Yorio, P. (1995) Aves marinas y costeras coloniales de la Península Valdés: revisión histórica y estado actual de sus poblaciones. Informes Técnicos del Plan de Manejo Integrado de la Zona Costera Patagónica. Fundación Patagonia Natural (Puerto Madryn, Argentina) 1: 1-21. 
Bibby, C.J., Burgess, N.D. and Hill, D.A. (1992) Bird census techniques. London: Academic Press.

Boersma, P.D., Stokes, D.L. and Yorio, P.M. (1990) Reproductive variability and historical change of Magellanic Penguins (Spheniscus magellanicus) at Punta Tombo, Argentina. Pp. 15-43 in L. Davis and J. Darby, eds. Penguin biology. San Diego: Academic Press.

Boswall, J. and Prytherch, R.J. (1972) Some notes on the birds of Point Tombo, Argentina. Bull. Brit. Orn. Club 92: 118-129.

Capurro, A., Frere, E., Gandini, M., Gandini, P., Holik, T., Lichtschein, V. and Boersma, P.D. (1988) Nest density and population size of Magellanic Penguins (Spheniscus magellanicus) at Cabo Dos Bahías. Auk 105: 585-588.

Carrara, I.S. (1952) Lobos marinos, pingüinos y guaneras de las costas del litoral maritimo e islas adyacentes de la República Argentina. Publicación Especial de la Universidad Nacional de Ciencias Veterinarias. La Plata.

Carribero, A., Pérez, D. and Yorio, P. (1995) Actualización en la distribución y abundancia del pingüino de Magallanes en Península Valdés, Chubut. El Hormero 14: 33-37.

Chebez, J.C. and Bertonatti, C.C. (1994) La avifauna de la Isla de los Estados, Islas de Año Nuevo y mar circundante (Tierra del Fuego, Argentina). Monografía Especial 1. Buenos Aires: Literature of Latin America.

Clark, G.S., Cowan, A., Harrison, P. and Bourne, W.R.P. (1992) Notes on the seabirds of the Cape Horn Islands. Notornis 39: 133-144.

Collar, N., Gonzaga, L., Krabbe, N., Madroño Nieto, A.G., Naranjo, L.G., Parker, T.A. and Wege, D. (1992) Threatened birds of the Americas: the ICBP Red Data Book. Cambridge, U.K.: International Council for Bird Preservation.

Commendatore, M., Gil, M., Harvey, M., Colombo, J.C. and Esteves, J.L. (1996) Evaluación de la contaminación por hidrocarburos y metales en la zona costera patagónica. Informes Técnicos del Plan de Manejo Integrado de la Zona Costera Patagónica. Fundación Patagonia Natural (Puerto Madryn) 21: 1-47.

Daciuk, J. (1977a) Notas faunísticas y bioecológicas de Península Valdes y Patagonia. VI. Observaciones sobre áreas de nidificación de la avifauna del litoral marítimo patagónico (Provincia del Chubut y Santa Cruz, R.A.). Segunda Parte. El Hornero 11: 361-376.

Daciuk, J. (1977b) Notas faunísticas y bioecológicas de Península Valdes y Patagonia. V. Anillado de aves en el litoral marítimo patagónico para estudios del comportamiento migratorio (Provincias de Chubut y Santa Cruz, Rep. Argentina). El Hornero 11: 349360.

Devillers, P. (1977) Observations at a breeding colony of Larus (belcheri) atlanticus. Gerfaut 67: 22-43

Devillers, P. (1978) Distribution and relationships of South American skuas. Gerfaut 68: $374-417$.

Erize, F.J. (1972) The Guanay Cormorant Phalacrocorax bougainvilli nesting on the Atlantic coast of South America. Bull. Brit. Orn. Club 92: 117-118.

Fowler, G.S., Wingfield, J.C. and Boersma, P.D. (1995) Hormonal and reproductive effects of low levels of petroleum fouling in Magellanic Penguins (Spheniscus magellanicus). Auk 112: $382-389$.

Frere, E. and Gandini, P. (1996) Conceptos generales para la evaluación y monitoreo de poblaciones de aves marinas. Informes Técnicos del Plan de Manejo Integrado de la Zona Costera Patagónica. Fundación Patagonia Natural (Puerto Madryn) 8: 1-29.

Frere, E., Gandini, M., Gandini, P., Holik, T., Lichtschein, V. and Oliva Day, M. (1993) Variación anual en el número de adultos reproductivos en una nueva colonia del Pingüino Penacho Amarillo Eudyptes crestatus (Spheniscidae) en Isla Pingüino (Santa Cruz, Argentina). El Hornero 13: 293-294.

Frere, E., Gandini, P. and Lichtschein, V. (1996) Variación latitudinal en la dieta del pin- 
güino de Magallanes (Spheniscus magellanicus) en la costa patagónica, Argentina. Orn. Neotrop. 7: 35-41.

Fundación Patagonia Natural (1996) Plan de Manejo Integrado de la Zona Costera Patagónica: diagnosis y recomendaciones para su elaboración. Puerto Madryn: Fundación Patagonia Natural and Wildlife Conservation Society.

Gandini, P. and Frere, E. (1995) Distribución, abundancia y ciclo reproductivo del Cormorán Gris Phalacrocorax gaimardi en la costa Patagónica, Argentina. El Hornero 14: 57-60.

Gandini, P. and Frere, E. (1996) Pautas para el uso turístico-recreativo de las colonias de aves de la Ría Deseado e Isla Pingüino, Santa Cruz. Informes Técnicos del Plan de Manejo Integrado de la Zona Costera Patagónica. Fundación Patagonia Natural (Puerto Madryn) 19: 1-22.

Gandini, P., Boersma, P.D., Frere, E., Gandini, M., Holik, T. and Lichtschein, V. (1994) Magellanic Penguins (Spheniscus magellanicus) affected by chronic petroleum pollution along the coast of Chubut, Argentina. Auk 111: 20-27.

Gandini, P., Frere, E. and Boersma, P.D. (1996) Status and conservation of the Magellanic penguin (Spheniscus magellanicus) in Patagonia, Argentina. Bird Conserv. Internatn. 6: $307-316$.

Gandini, P., Frere, E., Yorio, P. and Bertellotti, M. (1998) Métodos utilizados para los relevamiento y censos y criterios aplicados en la elaboración del Atlas. Pp. 15-18 in P. Yorio, E. Frere, P. Gandini and G. Harris, eds. Atlas de la distribución reproductiva de aves marinas en el litoral Patagónico Argentino. Plan de Manejo Integrado de la Zona Costera Patagónica. Fundación Patagonia Natural and Wildlife Conservation Society. Buenos Aires: Instituto Salesiano de Artes Gráficas.

Giaccardi, M., Yorio, P. and Lizurume, M. E. (1997) Patrones estacionales de abundancia de la gaviota cocinera (Larus dominicanus) en un basural patagónico y sus relaciones con el manejo de residuos urbanos y pesqueros. Orn. Neotrop. 8: $77^{-84}$

Gil, M., Harvey, M., Beldoménico, H., García, S., Commendatore, M., Gandini, P., Frere, E., Yorio, P., Crespo, E. and Esteves, J.L. (1997) Contaminación por metales y plaguicidas organoclorados en organismos marinos de la zona costera patagónica. Informes Técnicos del Plan de Manejo Integrado de la Zona Costera Patagónica. Fundación Patagonia Natural (Puerto Madryn) 32: 1-28.

Gochfeld, M. and Burger, J. (1996) Family Sternidae (Terns). Pp. 624-667 in J. del Hoyo, A. Elliott and J. Sargatal, eds. Handbook of the birds of the world, 3. Hoatzin to Auks. Barcelona: Lynx Editions.

Godoy, J.C. (1963) Fauna Silvestre. C.F.I. tomo VIII, vol. 1-2. Buenos Aires.

González, P., Bertellotti, M., Giaccardi, M., Lini, R., Lizurume, M.E. and Yorio, P. (1998) Distribución reproductiva y abundancia de las aves marinas de Río Negro. Pp. 29-37 in P. Yorio, E. Frere, P. Gandini and G. Harris, eds. Atlas de la distribución reproductiva de aves marinas en el litoral Patagónico Argentino. Plan de Manejo Integrado de la Zona Costera Patagónica. Fundación Patagonia Natural and Wildlife Conservation Society. Buenos Aires: Instituto Salesiano de Artes Gráficas.

Humphrey, P.S., Bridge, D., Reynolds, P.D. and Peterson, R.T. (1970) Birds of Isla Grande (Tierra del Fuego). Preliminary Smithsonian Manual. Washington, D.C: Smithsonian Institution.

Malacalza, V.E. (1984) Aves guaneras. Relevamiento de especies en tres cormoraneras continentales de la Provincia del Chubut. Contr. Centro Nacional Patagónico 84: 1-13.

Malacalza, V.E. (1991) External characters in the offspring resulting from cross-breeding between cormorant species. Colon. Waterbirds 14: 180-183.

Pagnoni, G., Perez, D. and Bertellotti, M. (1993) Distribución, abundancia y densidad de nidos en la Isla de los Pájaros, Chubut, Argentina. Actas II Jornadas Nacionales de Ciencias del Mar. Puerto Madryn, Chubut, Argentina, Septiembre 1991.

Pérez, F., Sutton, P. and Vila, A. (1995) Aves y mamíferos marinos de Santa Cruz. Recopi- 
lación de los relevamientos realizados entre 1986 y 1994. Boletín Técnico de la Fundación Vida Silvestre Argentina 26: 1-52.

Punta, G. (1989) Guaneras de la Provincia del Chubut. Potencialidad productiva y fundamentos para su manejo racional. Rawson: Dir. Imp. Of.

Punta, G. (1996) Estado de situación del recurso guanero en la República Argentina. Informes Técnicos del Plan de Manejo Integrado de la Zona Costera Patagónica. Fundación Patagonia Natural (Puerto Madryn, Argentina) 6: 1-57.

Punta, G. and Saravia, J. (1993) Distribución, abundancia y aspectos de la biología reproductiva del Cormorán Cuello Negro Phalacrocorax magellanicus en la Provincia del Chubut, Argentina. El Hornero 13: 295-298.

Rasmussen, P.C. (1991) Relationships between coastal South American King and Blueeyed Shags. Condor 93: 825-839.

Schiavini, A. and Yorio, P. (1995) Distribution and abundance of seabird colonies in the Argentine sector of the Beagle Channel, Tierra del Fuego. Mar. Orn. 23: 39-46.

Schiavini, A., Yorio, P. and Frere, E. (1998) Distribución reproductiva y abundancia de las aves marinas de la Isla Grande de Tierra del Fuego, Isla de los Estados e Islas de Año Nuevo (Provincia de Tierra del Fuego, Antártida e Islas del Atlántico Sur). Pp. 179-221 in P. Yorio, E. Frere, P. Gandini and G. Harris, eds. Atlas de la distribución reproductiva de aves marinas en el litoral Patagónico Argentino. Plan de Manejo Integrado de la Zona Costera Patagónica. Fundación Patagonia Natural and Wildlife Conservation Society. Buenos Aires: Instituto Salesiano de Artes Gráficas.

Scolaro, J.A., Rodrigez, E. and Monochio, A. (1980) El pingüino de Magallanes (Spheniscus magellanicus). V. Distribución de las colonias de reproducción en el territorio continental Argentino. Contr. Centro Nacional Patagónico 33: 1-18.

Scolaro, J.A., Laurenti, S. and Gallelli, H. (1996) The nesting and breeding biology of the South American Tern in northern Patagonia. J. Field Orn. 67: 17-24.

Siegel-Causey, D. (1986) The courtship behavior and mixed-species pairing of King and Imperial Blue-eyed Shags (Phalacrocorax albiventer and P. atriceps). Wilson Bull. 98: 571580.

Spivak, E. and Sanchez, N. (1992) Prey selection by Larus belcheri atlanticus in Mar Chiquita lagoon, Buenos Aires, Argentina: a posible explanation for its discontinuos distribution. Rev. Chil. Hist. Nat. 65: 209-220.

Tagliorette, A. and Losano, P. (1996) Demanda turística en áreas costeras protegidas de la Patagonia. Informes Técnicos del Plan de Manejo Integrado de la Żona Costera Patagónica. Fundación Patagonia Natural (Puerto Madryn, Argentina) 25: 1-30.

Vila, A.R. and Pérez, F. (1996) Apostaderos de aves y mamíferos marinos de Monte Loayza, Santa Cruz: pautas de manejo frente al potencial uso turístico del área. Informes Técnicos del Plan de Manejo de la Zona Costera Patagónica. Fundación Patagonia Natural (Puerto Madryn, Argentina) 15: 1-57.

Yorio, P. and Boersma, P.D. (1992) The effects of human disturbance on Magellanic Penguin behavior and breeding success. Bird Conserv. Internatn. 2: 161-173.

Yorio, P. and Caille, G. (1999) Seabird interactions with coastal fisheries in northern Patagonia: use of discards and incidental captures in nets. Waterbirds 22: 207-216.

Yorio, P. and Harris, G. (1997) Distribución reproductiva de aves marinas y costeras coloniales en Patagonia: relevamiento aéreo Bahía Blanca-Cabo Vírgenes, Noviembre 199o. Informes Técnicos del Plan de Manejo Integrado de la Zona Costera Patagónica. Fundación Patagonia Natural (Puerto Madryn) 29: 1-31.

Yorio, P. and Quintana, F. (1996) Efectos del disturbio humano sobre una colonia mixta de aves marinas en Patagonia. El Hornero 14: 89-96.

Yorio, P., Bertellotti, M., Gandini, P. and Frere, E. (in press) Kelp gulls (Larus dominicanus) breeding on the argentine coast: population status and relationship with coastal management and conservation. Mar. Orn. 
Yorio, P., Frere, E., Gandini, P. and Harris, G. (eds.) (1998) Atlas de la distribución reproductiva de aves marinas en el litoral Patagónico Argentino. Plan de Manejo Integrado de la Zona Costera Patagónica. Fundación Patagonia Natural and Wildlife Conservation Society. Buenos Aires: Instituto Salesiano de Artes Gráficas.

Yorio, P., Gandini, P., Frere, E. and Giaccardi, M. (1996a) Uso de basurales urbanos por gaviotas: magnitud del problema y metodologías para su evaluación. Informes Técnicos del Plan de Manejo Integrado de la Zona Costera Patagónica. Fundación Patagonia Natural (Puerto Madryn, Argentina) 22: 1-23.

Yorio, P., Swann, S. and Boersma, P.D. (1996b) Breeding biology of the dolphin gull (Larus scoresbii) at Punta Tombo, Argentina. Condor 98: 208-215.

Yorio, P., Gandini, P. and Frere, E. (1996c) Disturbios humanos sobre las aves marinas: efectos sobre la reproducción y su relación con el manejo de visitantes a las colonias. Informes Técnicos del Plan de Manejo Integrado de la Zona Costera Patagónica. Fundación Patagonia Natural (Puerto Madryn, Argentina) 23: 1-18.

Yorio, P., Punta, G., Rábano, D., Rabuffetti, F., Herrera, G., Saravia, J. and Friedrich, P. (1997) Newly discovered breeding sites of Olrog's Gull Larus atlanticus in Argentina. Bird Consero. Internatn. 7: 161-165

Yorio, P., Quintana, F., Campagna, C. and Harris, G. (1994) Diversidad, abundancia y dinámica espacio-temporal de la colonia mixta de aves marinas en Punta León, Patagonia. Orn. Neotrop. $5 \div 69-77$.

Zapata, A.R.P. (1965) Nuevas localidades de nidificacion de Leucophaeus scoresbii (Traill) y Sterna sandvicensis eurygnatha Saunders (Aves, Laridae). Physis 25: 383-385.

\section{PABLO YORIO}

Centro Nacional Patagónico, Fundación Patagonia Natural, and Wildlife Conservation Society, Bv. Brown s/n, 9120, Puerto Madryn, Chubut, Argentina. E-mail: yorio@cenpat.edu.ar

ESTEBAN FRERE, PATRICIA GANDINI

Universidad Nacional de la Patagonia Austral and Fundación Patagonia Natural, Almirante Zar 323, 9050, Puerto Deseado, Santa Cruz, Argentina.

WILLIAM CONWAY

Wildife Conservation Society, 2300 Southern Boulevard, Bronx, New York, NY-10460, USA. 